\title{
Influence of Secondary Prevention and Risk Factors to Recurrent Miocard Infark on Acute Coronary Syndrome Patients in General Hospital Surakarta Indonesia
}

\author{
https://doi.org/10.3991/ijoe.v15i10.10872 \\ Hidayah Karuniawati ${ }^{\bowtie}$, Vionella Moutika Putri \\ Universitas Muhammadiyah Surakarta, Beranda, Malaysia \\ hk170@ums.ac.ids \\ Tuqa Haitham \\ Universiti Sains Malaysia
}

\begin{abstract}
Patient who had myocardial infraction have a risk of recurrent myocardial infraction. Secondary prevention including antiplatelet, betablocker, statin, ACE inhibitor/ARB aims to prevent recurrent myocardial infarction. This study aimed to find the influence of secondary prevention and risk factors on the occurrence of recurrent myocardial infraction. This research was conducted with a quantitative and case control retrospectively. The subjects were 80 respondents consisting of 40 respondents in case group and 40 respondents in control group patients. Data were analyzed using bivariate analysis of chi square test followed by multivariate analysis of logistic regression. Rate of recurrent myocardial infarction (MI) with antiplatelet therapy decreased from $64.3 \%$ to $34.2 \%$, with beta-blocker therapy decreased from $57.7 \%$ to $35.7 \%$, with statin therapy decreased from $65.9 \%$ to $30.5 \%$, with ACE inhibitor/ARB therapy decreased from $65.9 \%$ to $30.5 \%$, with a combination of fourth therapy reduced from $57.4 \%$ to $34.6 \%$. Chi square test showed that there was a statistically significant relationship between antiplatelet therapy $(p=0.007)$, statin therapy $(p=0.002)$, ACE inhibitor / ARB therapy $(p=0.002)$, family history ( $p$ $=0.011)$ and adherence $(p=0.007)$ to recurrent MI. While multivariate analysis of logistic regression showed that the variables influencing the incidence of recurrent myocardial infarction were did not use antiplatelet therapy $(\mathrm{P}=0,005$; $\mathrm{OR}=4.006)$ and statin therapy $(\mathrm{P}=0,029 ; \mathrm{OR}=3.111)$. The secondary prevention reduced the incident of recurrent myocardial infarction.
\end{abstract}

Keywords-Risk Factor, Recurrent Myocardial Infraction, Compliance, Secondary Prevention

\section{$1 \quad$ Introduction}

Acute Coronary Syndrome (ACS) is an acute clinical manifestation of Coronary Heart Disease (CHD) which has a risk of serious complications and death [1]. Acute Coronary Syndrome (ACS) is a term used to describe a condition of disease processes 
that include unstable angina pectoris (unstable angina / UA), non-Q wave myocardial infarction or myocardial infarction without ST segment elevation (Non-ST elevation myocardial infarction / NSTEMI), and Q-wave myocardial infarction or myocardial infarction with ST elevation myocardial infarction (STEMI) (Ministry of Health of the Republic of Indonesia, 2008).

Myocardial infarction is a clinical syndrome caused by coronary artery occlusion resulting in disruption of blood flow to the heart which causes heart muscle cells in the area of the dead artery supply. Blood flow in blood vessels stops after acute coronary obstruction, except for a small amount of collateral flow from the blood vessels. The area of the surrounding muscle that does not get very little blood flow or flow can not maintain heart function, so it is said to be infarcted [2].

Based on data from the study of the ARIC (Atherosclerosis Risk in Communities study) and CHS (Cardiovascular Health Study) from NHLBI (National Heart, Lung and Blood Institute) (2011) of 785,000 Americans experienced the first acute myocardial attack and experienced recurrent myocardial infarction of 470,000 people [3]. Patients who have a history of myocardial infarction should receive useful treatment to reduce the risk of ongoing myocardial infarction or other manifestations of vascular disease, this is known as secondary prevention NICE[4]. The main objective of secondary prevention after myocardial infarction is to reduce the recurrence or recurrence of myocardial infarction, reduce morbidity and mortality and improve quality of life [5]. Risk factors that cause myocardial infarction include lipid abnormalities (49.2\%); smoke $(35.7 \%)$; history of hypertension $(17.9 \%)$; diabetes $(9.9 \%)$; obesity $(20.1 \%)$; alcohol consumption (6.7\%); and low physical activity (12.2\%) [6].

The treatments used to prevent recurrent myocardial infarction are antiplatelet, ACE inhibitors / ARBs, beta-blockers, and statins [4, 7]. However, the reality in the field of patients who survived myocardial infarction had a risk of experiencing recurrent events and the risk of death was at least 5-6 times greater than patients who had no history of CHD [8]. It is necessary to study the effect of secondary prevention and risk factors on the incidence of recurrent myocardial infarction in patients with acute coronary syndrome

\section{$2 \quad$ Methods}

This study was a case control study with retrospective data collection. Sample was divided into two groups, namely the case group and the control group. The case group was an acute coronary syndrome patient who had recurrent myocardial infarction and the control group was an acute coronary syndrome patient who was diagnosed with a myocardial infarction but had never experienced recurrent myocardial infarction.

Before commencement of the study, approval was obtained from Health Research Ethics Committee of Dr. Moewardi Surakarta/School of Medicine Sebelas Maret University number $287 /$ III/HREC/2018. Sampling was done with a case ratio: control $=1$ : 1 . Samples were taken using consecutive sampling method. Subjects who came during the April-May 2018 period and fulfilled the inclusion and exclusion criteria 
were determined as case groups and control groups until the number of samples was met [9].

The inclusion criteria for the case group were patients with a diagnosis of acute coronary syndrome who had recurrent myocardial infarction after the first myocardial infarction. The inclusion criteria for the control group were patients with a diagnosis of acute coronary syndrome who had experienced myocardial infarction first and did not experience recurrent myocardial infarction. Exclusion criteria in this study were pregnant patients.

The independent variables in this study were antiplatelet therapy, beta blocker therapy, statin therapy, ACE inhibitor / ARB therapy, a combination of 4 therapies (antiplatelet, beta blockers, statins and ACE inhibitors / ARB), family history, age, sex, body mass index , smoking history, history of drinking alcohol, low physical activity, history of hypertension, systolic pressure, diastolic pressure, history of hyperlipidemia, total cholesterol levels, history of diabetes mellitus, blood sugar levels, and compliance. While the dependent variable in this study was the incidence of recurrent myocardial infarction.

In this study respondents were categorized as not using secondary prevention if the respondent was not given secondary prevention after the first myocardial infarction and the respondent was given secondary prevention after the first myocardial infarction but was not obedient in using it. While respondents who were categorized using secondary prevention were respondents who were given secondary prevention after the first myocardial infarction and were obedient in using it.

Primary data were obtained from interviews with patients about adherence to secondary preventive therapy and patient social history. Patient compliance was assessed using the MARS-5 questionnaire which previously tested the validity and reliability of the questionnaire. Validity and reliability tests were performed on 30 acute coronary syndrome patients who were diagnosed with acute coronary syndrome and had experienced myocardial infarction. The MARS-5 compliance questionnaire consists of 5 questions, namely:

1. I forgot to take my medication

2. I changed the dosage of my medication

3. I stopped taking the medicine for some time

4. I passed the schedule of taking my medication 1 or more times 1 day

5. I take less medication than the rules stated

Each question has a score level for each answer $(1=$ always, $2=$ often, $3=$ sometimes, $4=$ rare, and $5=$ never). The value of compliance can be interpreted with high compliance with the total value of MARS score 25, moderate compliance with the total value of MARS score 6-24, and low compliance with a total value of MARS 1-5 scores [10]. Compliance assessment is measured using Medication Adherence Rating Scale-5 (MARS-5), respondents are said to be disobedient if the results of the compliance questionnaire fall into the category of moderate compliance and low compliance, while respondents are said to be compliant if the results of the compliance questionnaire fall into the high compliance category. The results obtained $\mathrm{r}$ count five questions were $0.627 ; 0,659 ; 0,378,0,819$; and 0.659 and it was declared valid because $r$ 
count was greater than $r$ table which was 0.361. Cronbach's Alpha was 0.604, so the MARS-5 questionnaire in this study was reliable. Questionnaires are said to be reliable if the alpha value is at least 0.6 [11].

Secondary data were obtained from patients' medical records which included patient characteristics data, history of ilness, history of secondary preventive treatment (antiplatelet therapy, beta-blocker therapy, statin therapy, ACE inhibitor / ARB therapy and a combination of the four therapies) and objective data on patients including pressure systolic blood, diastolic blood pressure, blood sugar levels, and total cholesterol levels. The study was conducted on 80 respondents consisting of 40 respondents in the case group and 40 respondents in the control group.

Data were analyzed by chi square test and logistic regression. Chi square test was used to analyze the relationship between secondary preventive therapy and factors associated with the incidence of recurrent myocardial infarction in the case group and control group. While logistic regression test was used to analyze the effect of several variables on the incidence of recurrent myocardial infarction.

\section{$3 \quad$ Results}

Compliance in treatment is an important thing that must be done by patients with a diagnosis of myocardial infarction. It aims to prevent recurrent attacks and sudden death [12]. The description of compliance with acute coronary syndrome patients can be seen in table 1 .

Table 1. Patients' Adherence Level

\begin{tabular}{|l|c|c|c|c|}
\hline & \multicolumn{2}{|c|}{ Case } & \multicolumn{2}{c|}{ Control } \\
\hline & $\mathbf{n = 4 0}$ & $\mathbf{4}$ & $\mathbf{n = 4 0}$ & $\mathbf{\%}$ \\
\hline High adherence & 12 & 30 & 25 & 62,5 \\
\hline Moderate adherence & 28 & 70 & 15 & 37,5 \\
\hline Low adherence & 0 & 0 & 0 & 0 \\
\hline
\end{tabular}

The results of bivariate statistical analysis using the chi square test the relationship between secondary prevention and risk factors with the incidence of recurrent myocardial infarction can be seen in tables 2 and 3. From the results of the chi square test showed that there were 6 variables that were statistically significant with $p<0.05$, namely : antiplatelet $(p=0.007)$, statin $(p=0.002)$, ACE inhibitor / ARB $(p=0.002)$, family history $(p=0.011)$ and adherence $(p=0.007)$.

Furthermore, to determine the effect of several variables with the incidence of recurrent myocardial infarction, multivariate logistic regression tests were carried out. From the results of the bivariate test, variables that have a $p$ value of $<0.25$ meet the requirements of the multivariate test. There were 10 variables that met the multivariate test, consist of antiplatelet therapy $(p=0.007)$, blocker beta therapy $(p=0.061)$, statin therapy $(p=0.002)$, ACE inhibitor / ARB therapy $(p=0.002), 4$ combination therapy $(p=0.056)$, family history $(p=0.011)$, low physical activity $(p=0.175)$, GDS level $(\mathrm{p}=0.160)$ and compliance $(\mathrm{p}=0.007)$. 
The results of multivariate logistic regression analysis, from 10 variables there are 2 variables that most influence the incidence of recurrent myocardial infarction that is not using antiplatelet therapy $(\mathrm{P}=0.005 ; \mathrm{OR}=4.066)$ and not using statin therapy ( $\mathrm{P}$ $=0.029 ; \mathrm{OR}=3.111)$. The results of multivariate logistic regression analysis can be seen in table 4.

Table 2. Relationship of Secondary Prevention on Recurrent Miocard Infark and Presentage of Recurrent Miocard Infark

\begin{tabular}{|c|c|c|c|c|c|c|c|c|c|}
\hline \multirow{2}{*}{$\begin{array}{l}\mathbf{N} \\
\mathbf{0}\end{array}$} & \multirow[t]{2}{*}{ Variable } & \multicolumn{2}{|c|}{ Case } & \multicolumn{2}{|c|}{ Control } & \multirow{2}{*}{$\mathbf{P}$} & \multirow{2}{*}{$\begin{array}{l}\text { Odds } \\
\text { Ratio }\end{array}$} & \multirow{2}{*}{$\begin{array}{c}95 \% \\
\text { Confidence } \\
\text { Interval } \\
\end{array}$} & \multirow{2}{*}{$\begin{array}{l}\text { \% Recur- } \\
\text { rent MI }\end{array}$} \\
\hline & & $n=40$ & $\%$ & $n=40$ & $\%$ & & & & \\
\hline 1 & \multicolumn{9}{|c|}{ Antiplatelet } \\
\hline & No & 27 & 67,5 & 15 & 37,5 & \multirow{2}{*}{$0,007^{*}$} & \multirow{2}{*}{3,462} & \multirow{2}{*}{$\begin{array}{c}1,379 \pm \\
8,691\end{array}$} & 64,3 \\
\hline & Yes & 13 & 32,5 & 25 & 62,5 & & & & 34,2 \\
\hline \multirow[t]{3}{*}{2} & \multicolumn{9}{|c|}{ Beta bloker } \\
\hline & No & 30 & 75 & 22 & 55 & \multirow{2}{*}{0,061} & \multirow{2}{*}{2,454} & \multirow{2}{*}{$\begin{array}{c}0,950 \pm \\
6,339\end{array}$} & 57,7 \\
\hline & Yes & 10 & 25 & 18 & 45 & & & & 35,7 \\
\hline \multirow[t]{3}{*}{3} & \multicolumn{9}{|c|}{ Statin } \\
\hline & No & 28 & 70 & 15 & 37,5 & \multirow{2}{*}{$0,002 *$} & \multirow{2}{*}{4,394} & \multirow{2}{*}{$\begin{array}{c}1,709 \pm \\
11,295\end{array}$} & 65,9 \\
\hline & Yes & 12 & 30 & 25 & 62,5 & & & & 30,5 \\
\hline \multirow[t]{3}{*}{4} & \multicolumn{9}{|c|}{$A C E$ Inhibitor/ARB } \\
\hline & No & 28 & 70 & 15 & 37,5 & \multirow{2}{*}{$0,002 *$} & \multirow{2}{*}{4,394} & \multirow{2}{*}{$\begin{array}{c}1,709 \pm \\
11,295\end{array}$} & 65,9 \\
\hline & Yes & 12 & 30 & 25 & 62,5 & & & & 30,5 \\
\hline \multirow[t]{3}{*}{5} & \multicolumn{9}{|c|}{4 Combinations } \\
\hline & No & 31 & 77,5 & 23 & 57,5 & \multirow{2}{*}{0,056} & \multirow{2}{*}{2,546} & \multirow{2}{*}{$\begin{array}{c}0,964 \pm \\
6,726 \\
\end{array}$} & 57,4 \\
\hline & Yes & 9 & 22,5 & 17 & 42,5 & & & & 34,6 \\
\hline
\end{tabular}

* Statistical significance

Table 3. Relationship Patients' Demography and Risk Factors to Recurrent MI

\begin{tabular}{|c|c|c|c|c|c|c|c|c|}
\hline \multirow[t]{2}{*}{ No } & \multirow[t]{2}{*}{ Variable } & \multicolumn{2}{|c|}{ Case } & \multicolumn{2}{|c|}{ Control } & \multirow[t]{2}{*}{$\mathbf{P}$} & \multirow{2}{*}{$\begin{array}{l}\text { Odds } \\
\text { Ratio }\end{array}$} & \multirow{2}{*}{$\begin{array}{c}95 \% \text { Confi- } \\
\text { dence Interval }\end{array}$} \\
\hline & & $n=40$ & $\%$ & $n=40$ & $\%$ & & & \\
\hline 1. & \multicolumn{8}{|c|}{ Family History } \\
\hline & Yes & 20 & 50 & 9 & 22,5 & \multirow{2}{*}{$0,011^{*}$} & \multirow{2}{*}{3,444} & \multirow{2}{*}{$1,310 \pm 9,058$} \\
\hline & No & 20 & 50 & 31 & 77,5 & & & \\
\hline 2. & \multicolumn{8}{|c|}{$\geq 60$-year-old } \\
\hline & Yes & 19 & 47,5 & 28 & 45 & \multirow{2}{*}{0,370} & \multirow{2}{*}{0,387} & \multirow{2}{*}{$0,277 \pm 1,616$} \\
\hline & No & 21 & 52,5 & 12 & 55 & & & \\
\hline 3. & \multicolumn{8}{|c|}{ Sex } \\
\hline & Man & 31 & 77,5 & 28 & 70 & \multirow{2}{*}{0,446} & \multirow{2}{*}{1,476} & \multirow{2}{*}{$0,541 \pm 4,029$} \\
\hline & Women & 9 & 22,5 & 12 & 30 & & & \\
\hline 4. & \multicolumn{8}{|c|}{$B M I \geq 30 \mathrm{~kg} / \mathrm{m}^{2}$} \\
\hline & Yes & 1 & 2,5 & 4 & 10 & \multirow{2}{*}{0,359} & \multirow{2}{*}{0,230} & \multirow{2}{*}{$0,025 \pm 2,163$} \\
\hline & $\mathrm{No}$ & 39 & 97,5 & 36 & 90 & & & \\
\hline 5. & \multicolumn{8}{|c|}{ Cigarrete smoking } \\
\hline & Yes & 26 & 65 & 26 & 65 & \multirow{2}{*}{0,264} & \multirow{2}{*}{1} & \multirow{2}{*}{$0,399 \pm 2,506$} \\
\hline & No & 14 & 35 & 14 & 35 & & & \\
\hline 6. & \multicolumn{8}{|c|}{ Alcohol consumption } \\
\hline & Yes & 10 & 25 & 6 & 15 & \multirow{2}{*}{0,402} & \multirow{2}{*}{1,889} & \multirow{2}{*}{$0,613 \pm 5,818$} \\
\hline & No & 30 & 75 & 34 & 85 & & & \\
\hline 7. & \multicolumn{8}{|c|}{ Inactivity } \\
\hline
\end{tabular}




\begin{tabular}{|c|c|c|c|c|c|c|c|c|}
\hline & Yes & 20 & 50 & 26 & 65 & \multirow[t]{2}{*}{0,175} & \multirow[t]{2}{*}{0,538} & \multirow[t]{2}{*}{$0,219 \pm 1,322$} \\
\hline & No & 20 & 50 & 14 & 35 & & & \\
\hline 8. & \multicolumn{8}{|c|}{ History of hypertension } \\
\hline & Yes & 15 & 37,5 & 26 & 65 & \multirow[t]{2}{*}{1} & \multirow[t]{2}{*}{0,323} & \multirow[t]{2}{*}{$0,404 \pm 2,473$} \\
\hline & No & 25 & 62,5 & 14 & 35 & & & \\
\hline & \multicolumn{8}{|c|}{ Systolik $\geq 140 \mathrm{mmHg}$} \\
\hline & Yes & 14 & 35 & 15 & 37,5 & \multirow[t]{2}{*}{0,816} & \multirow[t]{2}{*}{0,897} & \multirow[t]{2}{*}{$0,360 \pm 2,234$} \\
\hline & No & 26 & 65 & 25 & 62,5 & & & \\
\hline & \multicolumn{8}{|c|}{ Dyastolik $\geq 90 \mathrm{mmHg}$} \\
\hline & Yes & 10 & 25 & 14 & 35 & \multirow[t]{2}{*}{0,329} & \multirow[t]{2}{*}{0,619} & \multirow[t]{2}{*}{$0,235 \pm 1,627$} \\
\hline & No & 30 & 75 & 26 & 65 & & & \\
\hline 9. & \multicolumn{8}{|c|}{ History of Hiperlipidemia } \\
\hline & Yes & 12 & 30 & 6 & 15 & \multirow[t]{2}{*}{0,478} & \multirow[t]{2}{*}{2,429} & \multirow[t]{2}{*}{$0,281 \pm 1,812$} \\
\hline & No & 28 & 70 & 34 & 85 & & & \\
\hline & \multicolumn{8}{|c|}{ Total Cholesterol $\geq 200 \mathrm{mg} / \mathrm{dL}$} \\
\hline & Yes & 9 & 21,5 & 13 & 32,5 & \multirow[t]{2}{*}{0,317} & \multirow[t]{2}{*}{0,603} & \multirow[t]{2}{*}{$0,223 \pm 1,630$} \\
\hline & No & 31 & 78,5 & 27 & 67,5 & & & \\
\hline 10. & \multicolumn{8}{|c|}{ History of DM Diabetes } \\
\hline & Yes & 11 & 27,5 & 26 & 65 & \multirow[t]{2}{*}{1} & \multirow[t]{2}{*}{0,204} & \multirow[t]{2}{*}{$0,375 \pm 2,669$} \\
\hline & No & 29 & 72,5 & 14 & 35 & & & \\
\hline & \multicolumn{8}{|c|}{ Blood Glucose $\geq 140 \mathrm{mg} / \mathrm{dL}$} \\
\hline & Yes & 11 & 27,5 & 17 & 42,5 & \multirow[t]{2}{*}{0,160} & \multirow[t]{2}{*}{0,513} & \multirow[t]{2}{*}{$0,201 \pm 1,308$} \\
\hline & No & 29 & 72,5 & 23 & 57,5 & & & \\
\hline 11. & \multicolumn{8}{|c|}{ Compliance } \\
\hline & No & 29 & 70 & 15 & 37,5 & $0,007 *$ & 3,500 & $1,386 \pm 8,835$ \\
\hline & Yes & 11 & 30 & 25 & 62,5 & & & \\
\hline
\end{tabular}

*Statistical significance

Table 4. Variables that Influence on Recurrent MI based on Logistic Regression Analyze

\begin{tabular}{|l|c|c|c|c|}
\hline \multicolumn{1}{|c|}{ Variable } & Koefisien & P & Odds Ratio & 95\% Confidence Interval \\
\hline Do not use antiplatelet therapy & 1,403 & $0,005^{*}$ & 4,066 & $1,534 \pm 10,778$ \\
\hline Do not use statin therapy & 1,135 & $0,029^{*}$ & 3,111 & $1,121 \pm 8,631$ \\
\hline
\end{tabular}

* Statistical significance

\section{Discussion}

The results of the bivariate chi square test showed that not using antiplatelet therapy after the first myocardial infarction had a significant relationship to the incidence of recurrent myocardial infarction with $\mathrm{p}=0.007$ and patients who did not use antiplatelet therapy had a risk of recurrent myocardial infarction of 3,462 times compared with patients who used antiplatelet therapy after the first myocardial infarction. The incidence in patients experiencing recurrent myocardial infarction without antiplatelet therapy was $64.3 \%$, whereas in patients taking antiplatelet therapy decreased to $34.2 \%$. Based on the results of multivariate tests not using antiplatelet therapy also affect the incidence of recurrent myocardial infarction, with a value of $p=0.005$ and a risk of experiencing recurrent myocardial infarction of 4.066 times compared with patients who use antiplatelet therapy after the first myocardial infarction. 
Myocardial infarction occurs due to occlusion or blockage in the coronary arteries thereby inhibiting blood flow in the heart, resulting in an imbalance between oxygen supply and oxygen demand [2]. Antiplatelet is needed to reduce platelet aggregation in the bloodstream to reduce the occurrence of blockages in the coronary arteries.

Antiplatelet is a drug that must be routinely given after myocardial infarction [13]. Low-dose aspirin (75-100 $\mathrm{mg}$ ) is a recommendation for the prevention of recurrent myocardial infarction [7]. For non-STEMI patients aspirin and clopidogrel should be given for 12 months [14]. Whereas for STEMI patients given a combination of aspirin and clopidogrel for a little over 2 weeks COMMIT[15].

Thromboxane A2 can cause vasoconstriction and induce platelet formation. Aspirin works by reducing platelet aggregation through stimulation thrombogenic by inhibiting the cyclooxygenase enzyme reaction on platelets and blocking the conversion of arachidonic acid to thromboxane A2 [16]. Clopidogrel is a derivative of thienopyridin which can inhibit adenosine 5-diphospate binding to platelet receptors, thus preventing platelet formation [17].

Based on the Antiplatelet Trialists' Collaboration [18] study, aspirin significantly reduced the incidence of recurrent myocardial infarction compared with placebo with an ARR value of $3.8 \%(\mathrm{NNT}=26)$. The incidence of recurrent myocardial infarction in administration of clopidogrel was $9.2 \%$ compared with placebo administration of $10.1 \%$ with a value of $p=0.002$ [15]. The combination of aspirin and clopidogrel shows a reduced risk of recurrent myocardial infarction compared to aspirin alone at $2.1 \%$ ARR $(\mathrm{NNT}=48)$ [14]. Antiplatelet therapy is a standard combination of aspirin and clopidogrel, producing better results than aspirin alone. Research shows that P2YI2 inhibitor activity in clopidogrel increases when combined with aspirin [4].

The results of the bivariate chi square test showed that not using statin therapy after the first myocardial infarction had a significant relationship to the incidence of recurrent myocardial infarction with $p$ value 0.002 and a risk of recurrent myocardial infarction of 4.394 times compared with patients using statin therapy after the first myocardial infarction. The incidence of patients with recurrent myocardial infarction without statin therapy was $65.9 \%$, whereas in patients taking statin therapy decreased to $30.5 \%$. Based on the results of the multivariate test did not use statin therapy affect the incidence of recurrent myocardial infarction, with a value of $p=0.029$ and have a risk of recurrent myocardial infarction of 3.111 times compared with patients using statin therapy after the first myocardial infarction.

The use of statins as secondary preventive therapy can reduce risk of recurrent myocardial infarction [19]. Mechanisme statins reduce the synthesis of cholesterol in the liver which works competitively by inhibiting the activity of HMG-CoA reductase. Decreased intracellular cholesterol concentration induces Low Density Lipoprotein Receptors (LDLR) on the surface of hepatocyte cells, resulting in increased extraction of LDL cholesterol from the blood and decreased LDL and Apo B concentrations containing lipoproteins including particles containing only TG [20]. Cholesterol is a fatty substance synthesized in the heart and needed by the body, cholesterol levels in the blood when excessive will cause blockage problems in the blood vessels of the brain and heart [21]. The presence of blockages in the heart arteries causes blood flow to the heart to be obstructed so that the heart muscle cells do not get a blood supply 
causing the heart muscle to not maintain heart function, this event is called myocardial infarction [2]. Statin administration is expected to prevent blockages in the heart arteries to avoid the occurrence of myocardial infarction. The results of Malaeny's [22] research showed that high total cholesterol levels had a 9.2 times greater chance of developing coronary heart disease with a value of $\mathrm{p}=0.004$.

Studies show that in a hospital treatment patients with statin intolerance have an increased risk of recurrent myocardial infarction compared to those who consume statins with high adherence [23]. A study in the department of US veterans placed statins as secondary prevention which had the greatest intensity in reducing the incidence of recurrent myocardial infarction [24].

\title{
5 Conclusion
}

Secondary prevention including antiplatelet therapy and statin therapy has the effect of reducing the incidence of recurrent myocardial infarction. The results showed that the administration of secondary preventive therapy reduced the incidence of recurrent myocardial infarction. The incidence of recurrent myocardial infarction with antiplatelet administration dropped from $64.3 \%$ to $34.2 \%$; with the administration of beta blockers dropped from $57.7 \%$ to $35.7 \%$; statin administration dropped from $65.9 \%$ to $30.5 \%$; with ACE Inhibitor / ARB giving down from $65.9 \%$ to $30.5 \%$; with the combination of 4 therapies decreased from $57.4 \%$ to $34.6 \%$. From the results of the chi square test showed that there were 6 variables that were statistically significant with $\mathrm{p}<0.05$, namely : antiplatelet $(\mathrm{p}=0.007)$, statin $(\mathrm{p}=0.002)$, ACE inhibitor / ARB $(p=0.002)$, family history $(p=0.011)$ and adherence $(p=0.007)$. The results of multivariate logistic regression analysis showed that the variables influencing the incidence of recurrent myocardial infarction were not using antiplatelet therapy $(\mathrm{P}=$ 0.005 ; $\mathrm{OR}=4.066)$ and statin therapy $(\mathrm{P}=0.029$; $\mathrm{OR}=3.111)$. This shows that patients who do not take antiplatelet therapy after the first myocardial infarction have a risk of recurrent 4.066 times myocardial infarction compared with patients taking antiplatelet therapy after the first myocardial infarction and not using statin therapy after the first myocardial infarction has a risk of recurrent myocardial infarction 3,111 times compared with patients taking statin therapy after the first myocardial infarction.

\section{Abbreviations}

\author{
ACS: Acute Coroary Syndromes \\ BMI: Body Mass Index \\ MI: Miocard Infarc
}




\section{$7 \quad$ References}

[1] Trisnohadi H., 2006, Buku Ajar Ilmu Penyakit Dalam Jilid III Edisi IV, Fakultas Kedokteran Universitas Indonesia, Jakarta.

[2] Guyton A.C., dan Hall J.E., 2007, Buku Ajar Fisiologi Kedokteran, EGC, Jakarta.

[3] American Hearth Association Heart Disease and Stroke Statistics, 2011. Terdapat di: http://circ.ahajournals.org/content/123/4/e18.full

[4] National Institute for Health and Care Excellence (NICE), 2013, Myocardial Infarction: Secondary Prevention of Myocardial Infarction in Primary and Secondary Care, Draft for Consultation NICE guideline, The Guideline Development Group, National Collaborating Centre, and NICE Project Team, 1-43. https://doi.org/10.1111/j.1742-1241.2007.01539.x

[5] Ergatoudes C., Thunstrom E., Rosengren A., Bjorck L., Bostrom, K.B., Falk K., and Fu M., 2016, Long-term Secondary Prevention of Acute Myocardial Infarction, (SEPAT)Guidelines Adherence and Outcome BMC cardiovascular disorders, 16(1),226. https://doi.org/10.1186/s12872-016-0400-6.

[6] Yusuf S., Hawken S., Ounpuu S., 2004, Effect of Potentially Modifiable Risk Factors Associated with Myocardial Infraction in 52 Countries (The INTERHEART study): CaseControl Study, Lancet, 364, 937-952. https://doi.org/10.1016/s0140-6736(04)17018-9

[7] Van der Elst M.E., Buurma H., Bouvy M.L., and De Boer A., 2003, Drug Therapy for Prevention of Recurrent Myocardial Infarction, Annals of Pharmacotherapy, 37(10), 14651477. https://doi.org/10.1345/aph.1c450

[8] Mendis S., Abegunde D., Yusuf S., Ebrahim S., Shaper G., Ghannem H., and Shengelia B., 2005. WHO Study on Prevention of Recurrences of Myocardial Infarction and Stroke (WHO-PREMISE), Bulletin of the World Health Organization, 83(11), 820-829.

[9] Dahlan, M.S., 2008, Statistik Untuk Kedokteran dan Kesehatan, Edisi V Seri Evidence Medicine 1, Salemba Medika, Jakarta.

[10] Horne R., 2004, The Medication Adherence Report Scale, University of Brighton, Brighton.

[11] Umar H., 2000, Metode Penelitian Untuk Skripsi dan Tesis Bisnis, Cetakan Ketiga, PT Raja Grafindo Persada, Jakarta.

[12] Mubasiroh L.Y., 2013, Kepatuhan Pasien Infark Miokard Akut (IMA) Dalam Melakukan Pengobatan Secara Teratur Di Poli Jantung RSUD DR. Harjono Ponorogo, Disertasi, Fakultas Ilmu Keperawatan, Universitas Muhammadiyah Ponorogo, Ponorogo. https://doi.org/10.24269/hsj.v2i2.154

[13] Lin V., Holman J.R., and Jamieson B., 2010, Which Drugs Should Post-MI Patients routinely receive?, Clinical Inquiries, The Journal of Family Practice, 59(9), 527-529.

[14] Yusuf S., Zhao F., Mehta S.R., 2001, Effects of Clopidogrel in Addition to Aspirin in Patients With Acute Coronary Syndromes Without ST-Segment Elevation, New England Journal of Medicine, 345(7), 494-502. https://doi.org/10.1056/nejmoa010746

[15] COMMIT (Clopidogrel and Metoprolol in Myocardial Infarction Trial) Collaborative Group. 2005. Addition of Clopidogrel to Aspirin in 45852 Patients with Acute Myocardial Infarction, Randomised Placebo-Controlled Trial, Lancet, 366, 1607-1621. https://doi.org/10.1016/s0140-6736(05)67660-X

[16] Roth G.J., and Majerus P.W., 1975, The Mechanism of the Effect of Aspirin on Human Platelets I, Acetylation of a Particulate Fraction Protein, The Journal of clinical investigation, 56(3), 624-632. https://doi.org/10.1172/jci108132

[17] Mills D.C., Puri R., Hu C.J., Minniti C., Grana G., Freedman M.D., and Colman R.W., 1992, Clopidogrel Inhibits the Binding of ADP Analogues to the Receptor Mediating Inhi- 
bition of Platelet Adenylate Cyclase. Arteriosclerosis, Thrombosis, and Vascular Biology, 12(4), 430-436. https://doi.org/10.1161/01.atv.12.4.430

[18] Antiplatelet Trialists' Collaboration, 1994, Collaborative overview of randomised trials of antiplatelet therapy Prevention of death, myocardial infarction, and stroke by prolonged antiplatelet therapy in various categories of patients, BMJ, 308(6921), 81-106. https://doi.org/10.1136/bmj.308.6921.81

[19] Cannon C.P., Braunwald E., McCabe C.H., Rader D.J,. Rouleau J.L., Belder R., Joyal S.V., Hill K.A., Pfeffer M.A., and Skene A.M., 2004, Pravastatin or Atorvastatin Evaluation and Infection Therapy-Thrombolysis in Myocardial Infarction 22 Investigators, Intensive versus moderate lipid lowering with statins after acute coronary syndromes, N Engl J Med, 350(15), 1495-1504. https://doi.org/10.1056/nejmoa040583

[20] Catapano A.L., Chairperson E.A.S., Ireland I.G., France M.J.C., Uk P.D., Uk J.H., Hobbs R., Perrone P., Riccardi G., Uk R.F.S., Uk D.W., France C.F., Israel D.H. and Uk R.H., 2011, ESC / EAS Guidelines for the Management of Dyslipidaemias The Task Force for the Management of Dyslipidaemias of the European Society of Cardiology ( ESC ) and the European, 1769-1818. https://doi.org/10.3410/f.718113552.793483967

[21] Siswono, 2006, Bahaya Dari Kolesterol Tinggi, Terdapat pada: http://www.gizi.net/cgibin/ berita/fullnews.cgi?newsid997059568,3524v.

[22] Malaeny C.S., Katuuk M., and Onibala F., 2017, Hubungan Riwayat Lama Merokok Dan Kadar Kolesterol Total Dengan Kejadian Penyakit Jantung Koroner Di Poliklinik Jantung RSU Pancaran Kasih Gmim Manado, Jurnal Keperawatan, 5(1).

https://doi.org/10.31227/osf.io/usgxa

[23] Boekhold S.M., Hovingh G.K., and Mora S., 2014, Very Low Levels of Atherogenic Lipoprotein and the Risk of Cardiovascular Events: a Meta-analysis of Statin Trials. J Am Coll Cardiol, 64, 485-494.

[24] Downs J.R., and O'Mally P.G., 2015, Management of Dyslipidemia for Cardiovascular Disease Risk Reduction: Synopsis of the 2014 U.S. Departement of Veteran Affairs and U.S. Department of Defense clinical practice guideline, Ann Intern Med, 163, 485-494. https://doi.org/10.7326/m15-0840

\section{Authors}

Hidayah Karuniawati works at Universitas Muhammadiyah in Surakarta.

Vionella Moutika Putri works at Universitas Muhammadiyah in Surakarta.

Fakultas Farmasi works at Universitas Muhammadiyah in Surakarta.

Tuqa Haitham works at the School of Pharmaceutical Science, Universiti Sains Malaysia.

Article submitted 2019-03-24. Resubmitted 2019-05-02. Final acceptance 2019-05-21. Final version published as submitted by the authors. 